\title{
Bivariate analysis of the hydrophobic textiles obtained by plasma treatment
}

\author{
DOI: $10.35530 / I T .070 .06 .1476$
}

RALUCA MARIA AILENI

LAURENTIU DINCA

SILVIA ALBICI

LILIOARA SURDU

\section{ABSTRACT - REZUMAT}

\section{Bivariate analysis of the hydrophobic textiles obtained by plasma treatment}

This paper presents aspects concerning the bivariate analysis of the textiles surfaces treated by RF plasma technologies (Ar RF plasma and SF6 RF plasma) to obtain the hydrophobic effect. Besides this, it was studied the remnant or temporary hydrophobic effect obtained by polytetrafluoroethylene (PTFE) thin-film by physical vapor deposition (PVD) technique and SF6 RF plasma technique. In this paper, there are presented the bivariate analysis of the parameters and characterization of hydrophobic textile samples (cotton $100 \%$ with mass $401 \mathrm{~g} / \mathrm{m}^{2}$ ) by investigation of the water contact angle using the device VCA OPTIMA and resistance to surface wetting by James Heal spray tester. The morphological modification of the textile was evaluated by scanning electron microscope with magnification x8000. Following these investigations there has been observed that the treatment with polytetrafluoroethylene is even more harmful to the environment, offering a hydrophobic effect resistant in time, for approximative 101 days, and the treatment by SF6 RF plasma confer a temporary effect for 24 hours.

Keywords: plasma, bivariate analysis, hydrophobicity, contact angle, resistance to surface wetting

Analiza bivariată a materialelor textile hidrofobe obținute prin tratarea în mediu de plasmă

Această lucrare prezintă aspecte privind analiza bivariată a suprafețelor textile tratate prin intermediul tehnologiilor RF plasmă (RF plasmă Ar şi RF plasmă SF6), pentru a obține efectul hidrofob. În plus, a fost studiat efectul remanent sau temporar hidrofob obținut prin depunerea unei pelicule subțiri de politetrafluoroetilenă (PTFE), prin tehnologia de depunere fizică sub formă de vapori (PVD) și RF plasma SF6. În această lucrare, sunt prezentate analiza bivariată a parametrilor și caracterizarea probelor textile hidrofobe (bumbac 100\% cu masă $401 \mathrm{~g} / \mathrm{m}^{2}$ ), prin determinarea unghiului de contact la apă cu ajutorul dispozitivului VCA OPTIMA și a rezistenței la umezire prin metoda Spray test (James Heal). Evaluarea modificărilor morfologice a fost realizată prin microscopie electronică SEM cu magnifiere x8000. În urma acestor investigații, s-a observat că tratamentul cu politetrafluoroetilenă este dăunător pentru mediu şi conferă un efect de hidrofobizare rezistent în timp pentru aproximativ 101 zile, iar tratamentul cu RF plasmă SF6 are un efect de hidrofobizare temporară pentru 24 de ore.

Cuvinte-cheie: plasmă, analiza bivariată, hidrofobicitate, unghiul de contact, rezistența la umezire

\section{INTRODUCTION}

The challenges to finding solutions for surface functionalization by low cost in materials, energy, and time, boost the research in textile to multidisciplinarity and new versatile technologies such as RF plasma technology or magnetron sputtering to deposit thinfilm on the textile surface. The new approach of PVD coating on the cotton textile surface [1-3] offers a new perspective for textile functionalization to obtain antibacterial [4], the hydrophobic [5-7], hydrophilic or conductive effect [8-9]. The magnetron sputtering [10] is high-rate vacuum coating technique for depositing metals, alloys, and compounds on the materials surface, with film thicknesses. The coating techniques based on vacuum deposition are chemical vapor deposition (CVD) [11] and physical vapor deposition (PVD) [12-14]. By CVD coating technology, a thin film was obtained by the chemical reaction between precursors. The inconvenient is that this technique requires a high-temperature medium. By PVD technique, the surface can be modified by evaporation and sputtering. This technique is eco-friendly and dry technology [15-17] that can be used for obtaining functional surfaces with hydrophobic, hydrophilic, antibacterial, electrical, mechanical properties improved. However, the most commonly used plasma technology for textile functionalization, such as hydrophobization and hydrophilic [18-19], still remains low pressure RF plasma technology.

\section{EXPERIMENTAL PART AND METHODS}

The goal of our experiments was to investigate the hydrophobic character, permanent or temporary, obtained by using RF plasma treatments based on Argon (Ar) and fluoropolymers such as PTFE (Polytetrafluoroethylene) or plasma treatments based SF6 (Sulfur hexafluoride). In order to achieve these objectives there were used several parameters that define the samples (cotton $100 \%$, mass $401 \mathrm{~g} / \mathrm{m}^{2}$ ) and experiments such as gas flow rate $(15-120 \mathrm{sccm})$, pressure $\left(1.0 \times 10^{-3}-8.8 \times 10^{-4} \mathrm{mbar}\right)$, time (5-15 $\left.\mathrm{min}\right)$, power $(40 \mathrm{~W} ; 80 \mathrm{~W}$ ) and gas type (SF6 or Argon for magnetron sputtering used for PTFE thin-film deposition). By RF plasma Ar and PTFE were prepared 
9 samples $\left(P_{1}-P_{9}\right)$ and by SF6 RF plasma were provided 6 samples $\left(P_{10}-P_{15}\right)$.

To investigate the resistance to surface wetting using a spray test qualitative method (SR EN ISO 4920: 2013) that allows appreciating, by ISO scale or photographic scale AATCC, the resistance of the fabric to surface wetting by water at temperature $21^{\circ} \mathrm{C}$. Using this method several tests were performed during 101 days. Figure 1 presents the values obtained by photographic scale AATCC during the 101 days for samples treated with PTFE in Ar RF plasma, and figure 2 presents the values for 3 days for samples treated with $\mathrm{SF}_{6} \mathrm{RF}$ plasma. By performing these tests, we observed that the fabric treated in RF plasma acquires a temporary hydrophobic character. Also, in the case of $\mathrm{SF}_{6} \mathrm{RF}$ plasma, the hydrophobic character was active only for $24 \mathrm{~h}$, and after 48 hours the fabrics become initial hydrophilic characters (figure 2). However, in case of the treatments obtained by $\mathrm{Ar}$ plasma with thin-film PTFE deposition the hydrophobic character (figure 1) was longtime remnant and on several samples was still active after 101 but with very weak values.

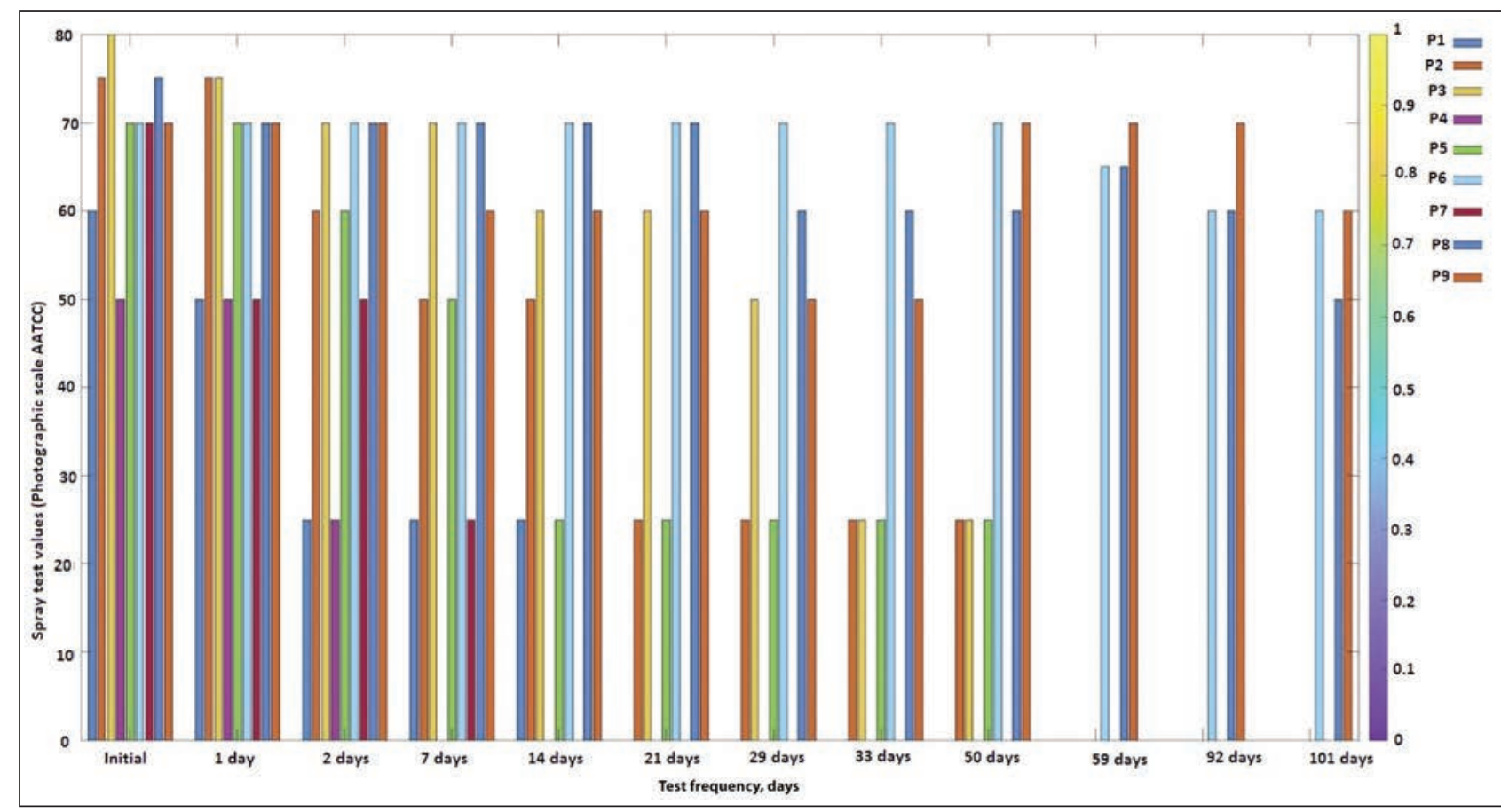

Fig. 1. Spray tests for samples $P_{1}-P_{9}$ treated in Ar plasma and coated with PTFE

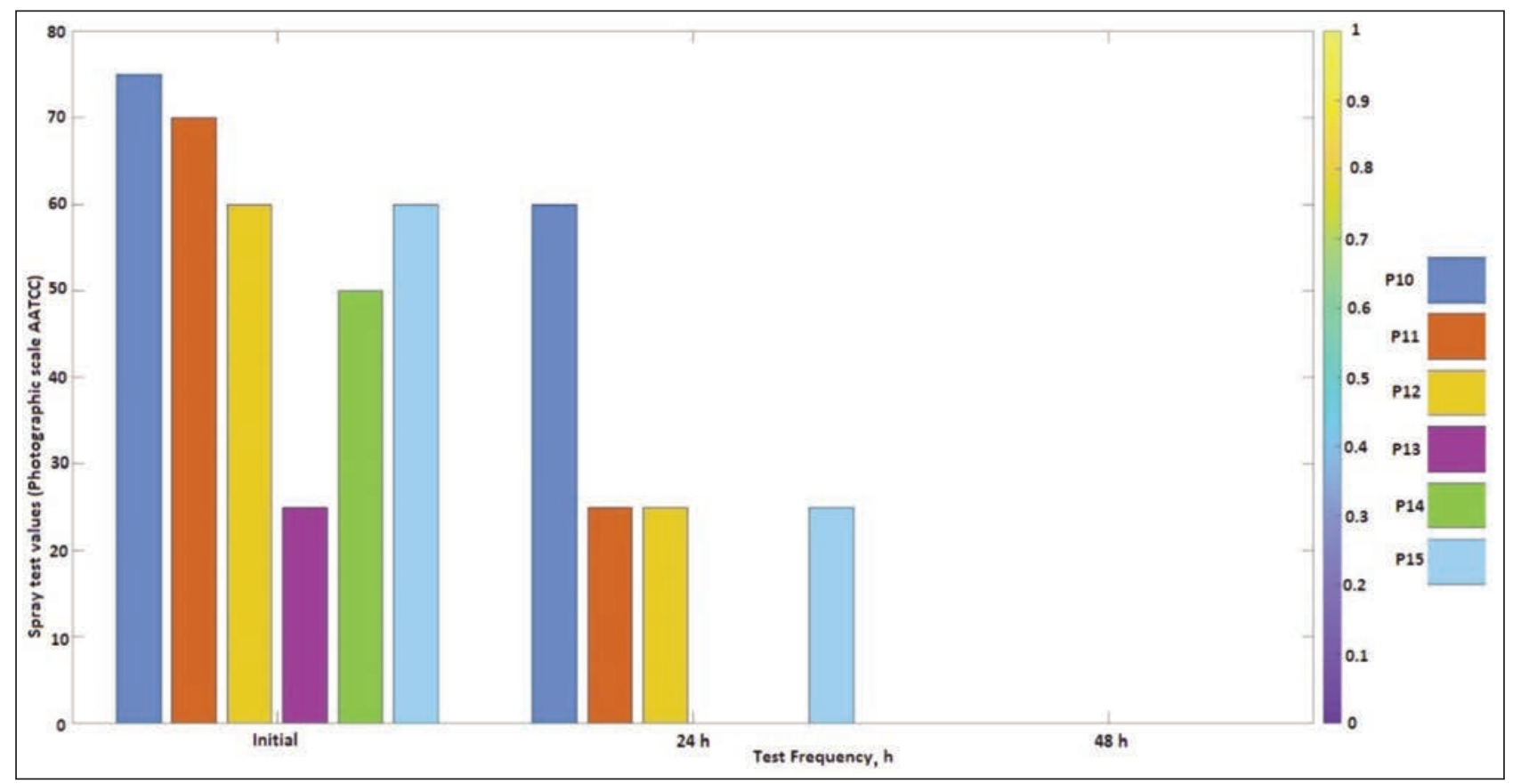

Fig. 2. Spray tests for samples $\mathrm{P}_{10}-\mathrm{P}_{15}$ treated using $\mathrm{SF}_{6} \mathrm{RF}$ plasma 


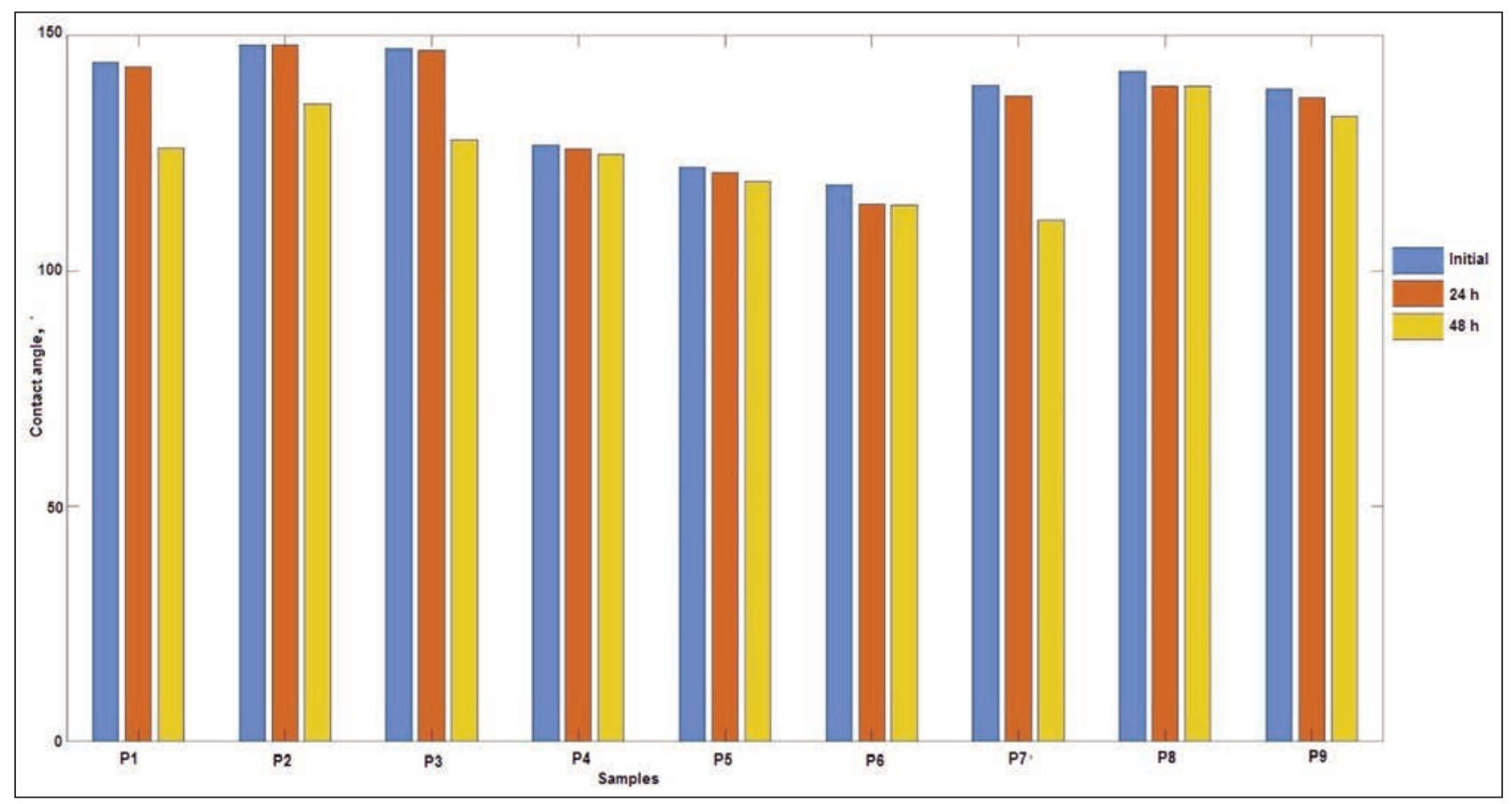

Fig. 3. Contact angles for samples P1-P9 for 3 days

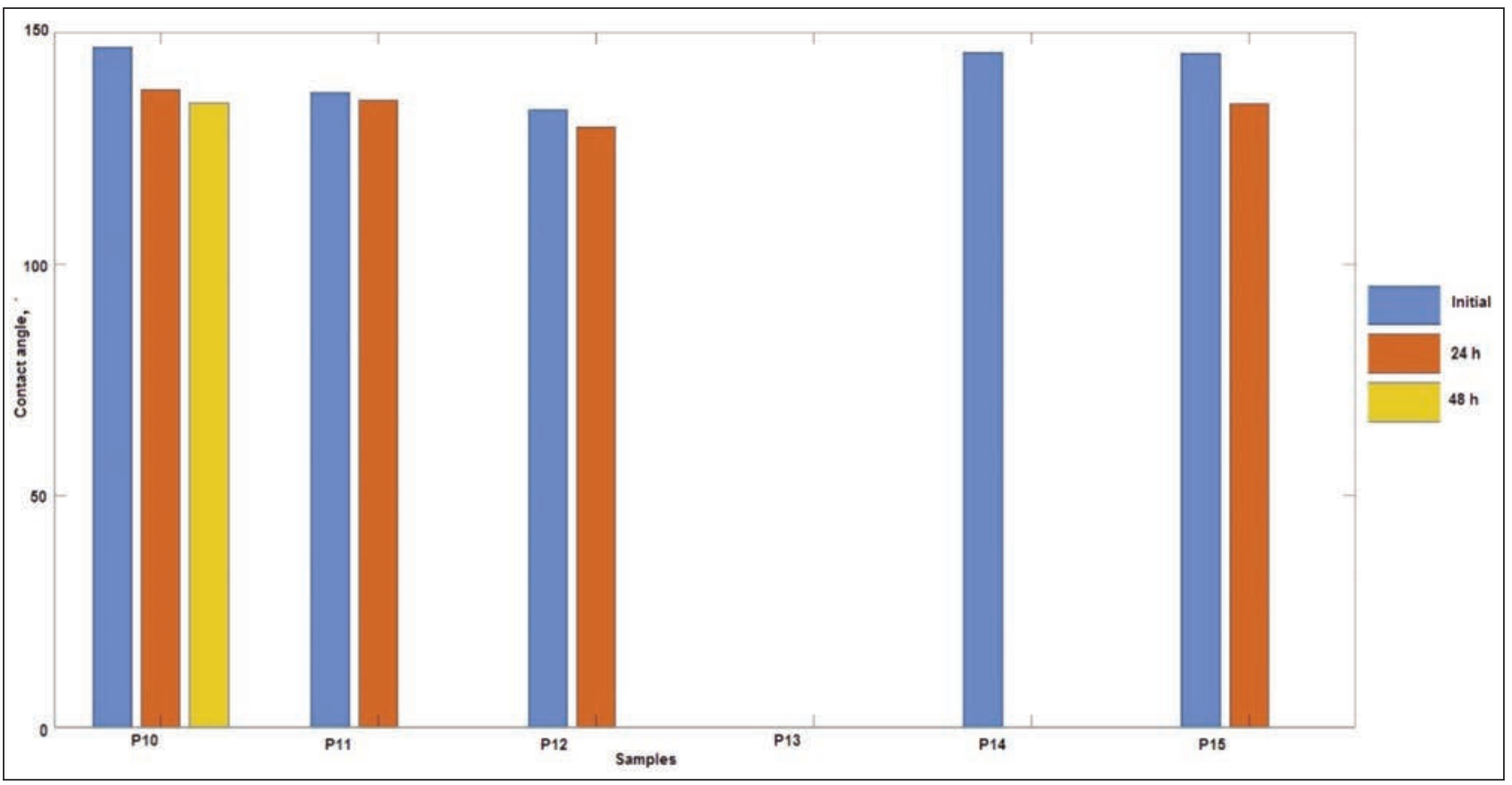

Fig. 4. Contact angles for samples P10-P15 for 3 days

Also, we analyzed the contact angle for samples with hydrophobic properties obtained by Ar RF plasma with thin-film PTFE (figure 3) and $\mathrm{SF}_{6}$ RF plasma (figure 4). The thickness of the PTFE thin-film was varied using the argon flow injected during the sputtering process (in the range $80-120 \mathrm{sccm}$ ), and respectively by the deposition time (5-15 min).

The hydrophobic effect of the coated textile surfaces was investigated by the water contact angle using the device VCA OPTIMA (figure 5) according to ASTM D7490-08 (table 1) and spray rating tester (resistance

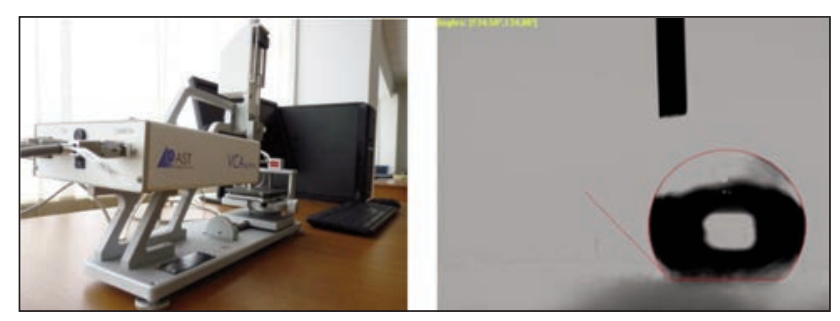

Fig. 5. Optima VCA - contact angle test

to surface wetting tester - figure 6) from James Heal according to SR EN ISO 4920/2013 (table 1). 


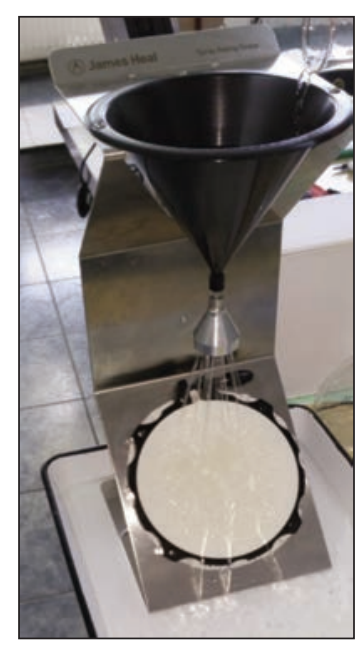

Fig. 6. Resistance to surface wetting tester James Heal
The morphological analysis was performed by using an electron scan microscope (SEM) with a view at $50 \mu \mathrm{m}$ scale with magnitude X8000 to highlight the morphological modifications (figure 7).

From all samples treated by RF plasma, the samples (M-etalon sample, P8, and P9 are samples coated by PTFE and Ar RF plasma technology) with the best values obtained to resistance to surface wetting test after 101 days, respective to water contact angle are presented in table 1.

$$
f(x)=a^{*} x^{4}+b^{*} x^{3}+c^{*} x^{2}+d^{*} x+e
$$

where: $x=P_{S F 6} ; f(x)=R_{S W} ; a=-26.82 ; b=3.213$; $c=89.43 ; d=-6.259 ; e=23.67$.

Besides, analyzing the covariations (cov) $\operatorname{cov}\left(R_{S W}\right.$ $\left.P_{S F 6}\right)(3)$ between resistance to surface wetting $\left(R_{S W}\right)$ and work pressure $\left(P_{S F 6}\right)$, respective $\operatorname{cov}\left(R_{S W}, \Phi_{S F 6}\right)$ (4) between $R_{S W}$ and gas flow rate $\left(\Phi_{S F 6}\right)$ we observed that resistance of surface wetting is in inverse proportionality report with both gas flow rate and gas pressure. That means that at the increasing of the values for pressure, respective floe rate, the resistance of surface wetting will have a decreasing trend.

$$
\begin{aligned}
& \operatorname{cov}\left(R_{S w^{\prime}}, P_{S F \sigma}\right)=\left|\begin{array}{ll}
0.0000 & -0.0011 \\
-0.0011 & 316.6667
\end{array}\right| \\
& \operatorname{cov}\left(R_{S w^{\prime}} \Phi_{S F \sigma}\right)=\left|\begin{array}{ll}
87.5000 & -85.0000 \\
-85.0000 & 316.6667
\end{array}\right|
\end{aligned}
$$

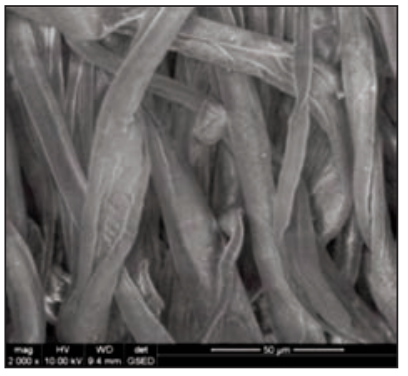

Etalon (M)

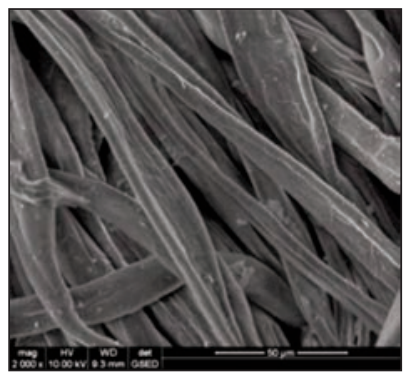

P6

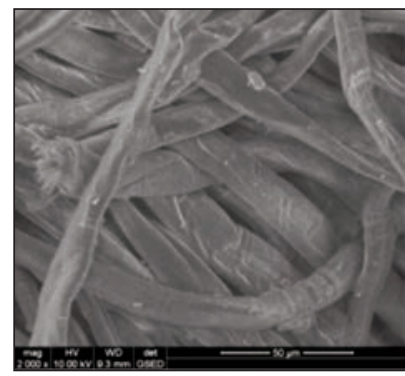

P8

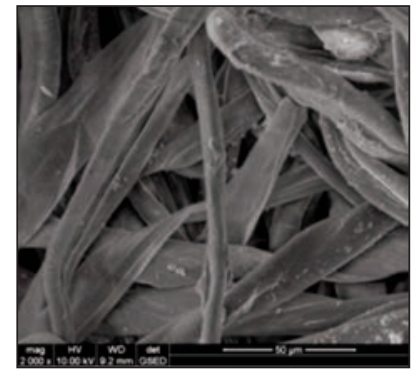

P9

Fig. 7. Morphological analysis for samples P6, P8, and P9 in comparison with the etalon

Table $1 \quad$ By analyzing data for samples treated

SAMPLE WITH HYDROPHOBIC CHARACTER OBTAINED IN

\begin{tabular}{|c|c|c|c|c|c|}
\hline \multirow{2}{*}{\multicolumn{2}{|c|}{ Tests }} & \multicolumn{3}{|c|}{ Results } & \multirow{2}{*}{ Standards } \\
\hline & & \multirow{2}{*}{$\frac{\mathbf{M}}{0}$} & \multirow{2}{*}{$\begin{array}{c}\text { P8 } \\
2\end{array}$} & \multirow{2}{*}{$\begin{array}{l}\text { P9 } \\
2.5\end{array}$} & \\
\hline $\begin{array}{l}\text { Resistance } \\
\text { to surface }\end{array}$ & $\begin{array}{l}\text { Degree scale } \\
\text { ISO }\end{array}$ & & & & \multirow{2}{*}{$\begin{array}{l}\text { SR EN ISO } \\
4920 / 2013\end{array}$} \\
\hline $\begin{array}{l}\text { wetting } \\
\text { (Spray test) }\end{array}$ & $\begin{array}{l}\text { Photographic } \\
\text { scale AATCC }\end{array}$ & 0 & 70 & 75 & \\
\hline \multicolumn{2}{|c|}{ Contact angle } & $<1$ & 142.4 & 138.6 & ASTM D7490-08 \\
\hline
\end{tabular}
PLASMA AND PERSISTENT HYDROPHOBIC CHARACTER FOR APPROX. 100 DAYS with RF plasma Ar (Argon) and PTFE, we observed that these could not provide a bivariate linear analysis and a multivariate analysis of data (figure 10) was performed. Figure 10 presents the multivariate analysis graph for resistance to surface wetting (photographic scale AATCC) depending on gas volume $\left(V_{A r}\right)$ (5) during the experiment time $(t)$ and pressure $\left(P_{A r}\right)$.

$$
V_{A r}=\Phi_{A r}{ }^{*} t
$$

\section{BIVARIATE ANALYSIS OF THE EXPERIMENTAL DATA}

We used bivariate analysis (figures 8 and 9) of two variables (resistance to surface wetting reported to gas flow rate and pressure) to investigate the dependence or the difference between two variables.

By bivariate analysis the resistance to surface wetting $\left(R_{s w}\right)=f\left(\Phi_{S F 6}\right)$ resulted the linear model (1):

$$
f(x)=a^{*} x^{5}+b^{*} x^{4}+c^{*} x^{3}+d^{*} x^{2}+e^{*} x+f
$$

where: $x=\emptyset_{\mathrm{SF} 6} ; f(x)=R_{s w} ; a=-50.61 ; b=-14.04$; $c=128.9 ; d=40.65 ; e=-74.43 ; f=39.67$.

By bivariate analysis the resistance to surface wetting $\left(R_{s w}\right)=f\left(P_{S F G}\right)$ resulted the linear model (2):
By multivariate analysis of the parameters, the resistance to surface wetting $\left(R_{s w}=f\left(P_{A r}, V_{A r}\right)\right.$ resulted the linear model (6):

$$
f(x, y)=a+b^{*} x+c^{*} y+d^{*} x^{2}+e^{*} x^{*} y+f^{*} y^{2}
$$

where: $\quad R_{s w}=f(x, y) ; \quad x=V_{A r} ; \quad y=P_{A r} ; \quad a=66.15$; $b=-2.992 ; c=7.208 ; d=8.75 ; e=-2.059 ; f=-4.913$. By analyzing the covariations $\operatorname{cov}\left(R_{S W}, P_{A r}\right)$ (7) between resistance to surface wetting $\left(R_{S W}\right)$ and work pressure $\left(P_{A r}\right)$, respective $\operatorname{cov}\left(R_{S W}, V_{A r}\right)(8)$ between $R_{s w}$ and gas volume $\left(V_{A r}\right)$ we observed that resistance of surface wetting is in direct proportionality report with gas volume, respective gas pressure, but the most substantial influence has the gas volume inserted in plasma installation. 


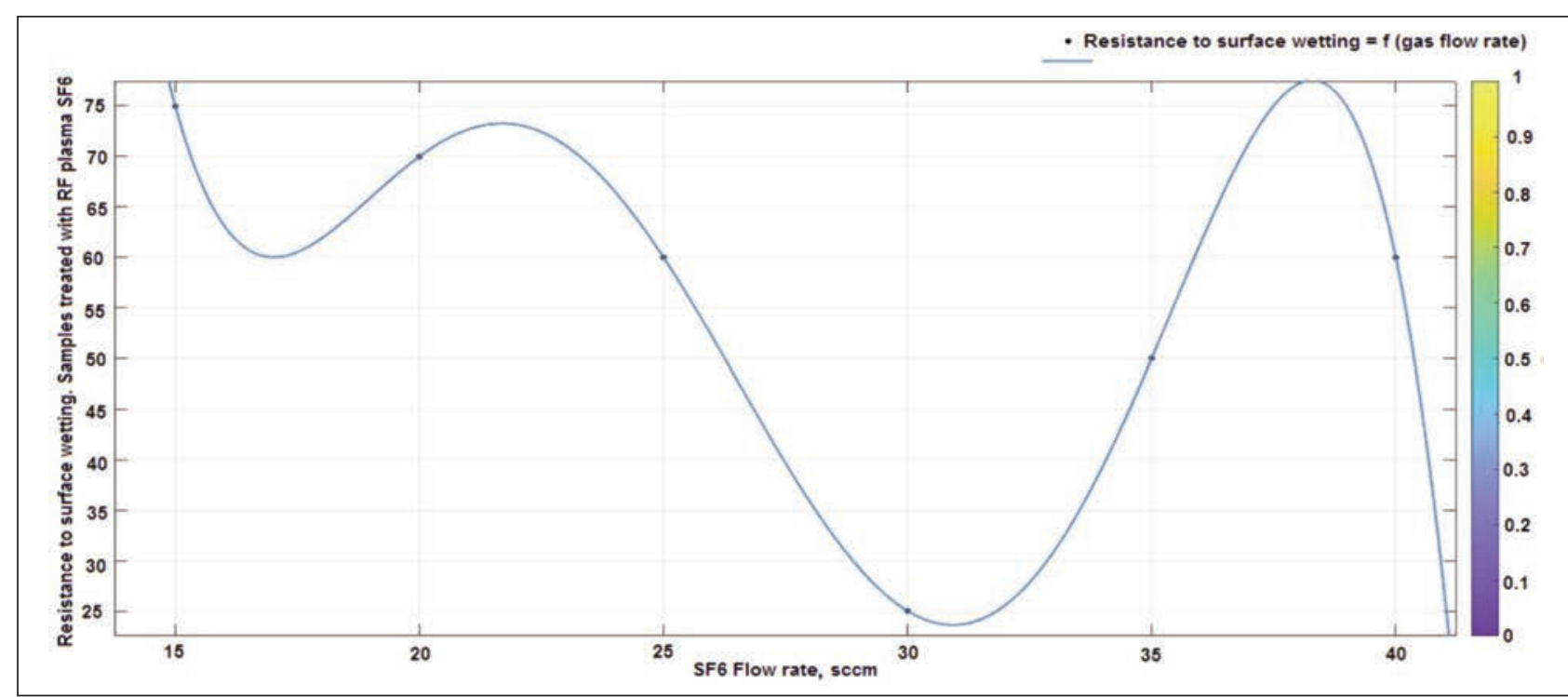

Fig. 8. Bivariate analysis $\rightarrow$ resistance to surface wetting $\left(R_{\text {sw }}\right)$ depending on the SF6 flow rate $\left(\Phi_{\text {SF } 6}\right)$-samples treated by $\mathrm{SF}_{6} \mathrm{RF}$ plasma

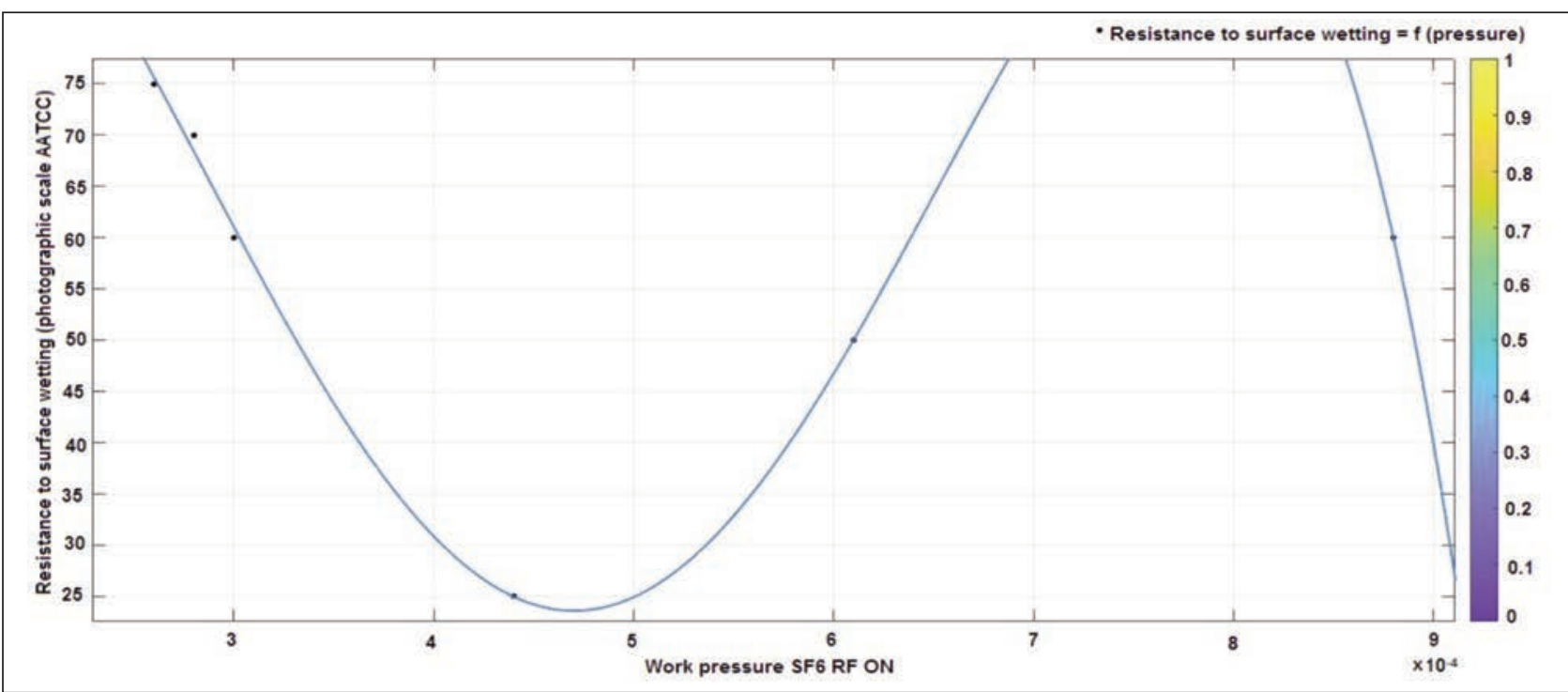

Fig. 9. Bivariate analysis $\rightarrow$ resistance to surface wetting $\left(R_{s w}\right)$ depending on the work pressure $\left(P_{S F 6}\right)$-samples treated by $\mathrm{SF}_{6} \mathrm{RF}$ plasma

$$
\begin{gathered}
\operatorname{cov}\left(R_{s w}, V_{A r}\right)=1.0 e+05 *\left|\begin{array}{cc}
2.2250 & 0.0225 \\
0.0225 & 0.0008
\end{array}\right| \\
\operatorname{cov}\left(R_{s w^{\prime}}, P_{A r}\right)=\left|\begin{array}{cc}
0.0000 & 0.0001 \\
0.0001 & 79.8611
\end{array}\right|
\end{gathered}
$$

\section{CONCLUSIONS}

The hydrophobic effect obtained by RF plasma technology has a temporary character (2-101 days) and has the advantages of reducing environmental waste and that it is a clean procedure. The substances used in plasma treatment are already reported harmful to human health. The resistance to surface wetting depends on the gas flow rate, time, and work pressure. In case of the samples treated by Ar RF plasma and PTFE was observed direct dependence between the resistance to surface wetting and the variations of gas volume, respective gas pressure used during the experiment. However, in the case of the samples treated with SF6 RF plasma it was observed an inverse dependence between the resistance of the surface wetting and the as flow rate or gas pressure variations during the experiment. Concerning the durability of the hydrophobization treatment it was observed that in case of the samples treated with SF6 the effect was temporary only for 24 hours, and after 48 hours was observed that samples become hydrophilic. Also, in case of the samples treated with Ar plasma and PTFE film deposition, the samples acquire a longtime hydrophobic effect, the last observations, after 101 days, indicating for two of the samples a remnant weak hydrophobic effect. In conclusion, the resistance to surface wetting and contact angle values are in a strong dependence, and the principal influence factors are time, drop speed, gas type, and temperature. 


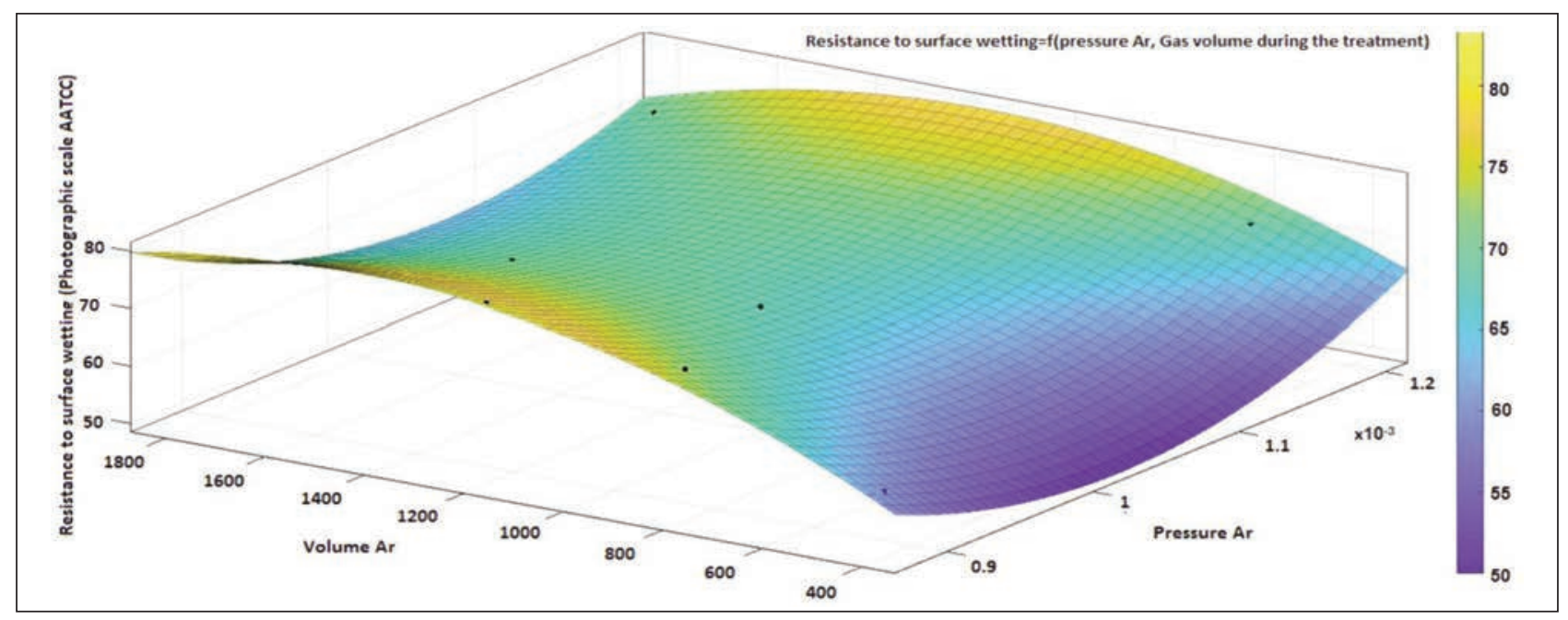

Fig. 10. 3D representation - resistance to surface wetting $\left(R_{s w}\right)$ related to the gas volume $\left(V_{A r}\right)$ and gas pressure $\left(P_{A r}\right)$

\section{ACKNOWLED GMENTS}

This research presented in this paper prepared in the INCDTP laboratories was funded by ANCSI, National Project "The assessment of the life cycle of the hydrophobic textile materials", Contract PN 16340407 . The treatments of the samples by SF6 RF plasma, Ar plasma, and PTFE deposition were performed by contract, using plasma equipment available at INFLPR.

\section{REFERENCES}

[1] Gulrajani, M.L., Deepti, G., Emerging techniques for functional finishing of textiles, 2011

[2] Vančo, M., Krmela, J., Pešlová, F., The use of PVD coating on natural textile fibers, In: Procedia Engineering, 2016, 136, 341-345

[3] Shahidi, S., Moazzenchi, B., Ghoranneviss, M., A review-application of physical vapor deposition (PVD) and related methods in the textile industry, In: The European Physical Journal Applied Physics, 2015, 71, 3, 31302

[4] Dubas, S.T., Kumlangdudsana, P., Potiyaraj, P., Layer-by-layer deposition of antimicrobial silver nanoparticles on textile fibers, In: Colloids and Surfaces A: Physicochemical and Engineering Aspects, 2006, 289, 1-3, 105-109

[5] Gashti, M.P., Alimohammadi, F., Shamei, A., Preparation of water-repellent cellulose fibers using a polycarboxylic acid/hydrophobic silica nanocomposite coating, In: Surface and Coatings Technology, 2012, 206, 14, 3208-3215

[6] Kabir, H., Matthess, J., Dietzel, Y., Offermann, P., Nocke, G., Matthess, K., PVD-coating for the processing of textiles, In: Research Journal of Textile and Apparel, 2004, 8, 1, 32-37

[7] Wei, Q., Xu, Y., Wang, Y., Textile surface functionalization by physical vapor deposition (PVD), In: Surface Modification of Textiles, 2009, ed Woodhead Publishing, 58-90

[8] Maity, S., Singha, K., Debnath, P., Singha, M., Textiles in electromagnetic radiation protection, In: Journal of Safety Engineering, 2013, 2, 2, 11-19

[9] Fu, K.K., Padbury, R., Toprakci, O., Dirican, M., Zhang, X., Conductive textiles, In Engineering of High-Performance Textiles, 2018 ed Woodhead Publishing, 305-334

[10] Kelly, P.J., Arnell, R.D., Magnetron sputtering: a review of recent developments and applications, In: Vacuum, 2000, 56, 3, 159-172

[11] Pierson, H. O., Handbook of chemical vapor deposition: principles, technology and applications, William Andrew, 1999

[12] Mattox, D. M., Handbook of physical vapor deposition (PVD) processing, William Andrew, 2010

[13] Seshan, K., Handbook of Thin Film Deposition, William Andrew, 2001

[14] Nee, A.Y.C., Handbook of manufacturing engineering and technology, Springer, 2015

[15] Lv, J., Zhou, Q., Zhi, T., Gao, D., Wang, C., Environmentally friendly surface modification of polyethylene terephthalate (PET) fabric by low-temperature oxygen plasma and carboxymethyl chitosan, In: Journal of cleaner production, 2016, 118, 187-196

[16] Shishoo, R. ed., Plasma technologies for textiles, Elsevier, 2007

[17] Romdhani, Z., Hamdaoui, M., Baffoun, A., Roudesli, S., General behavior and parameters affecting the Ink jet printing phenomenon on woven polyester fabric, In: Industria Textila, 2017, 68, 1, 37-46, https://doi.org/10.35530/IT.068.01.1327

[18] Haji, A., Shoushtari, A.M., Natural antibacterial finishing of wool fiber using plasma technology, In: Industria Textila, 2011, 62, 5, 244-247

[19] Haji, A., Qavamnia, S.S., Bizhaem, F. K., Optimization of oxygen plasma treatment to improve the dyeing of wool with grape leaves, In: Industria Textila, 2016, 67, 4, 244-249

\section{Authors:}

RALUCA MARIA AILENI, SILVIA ALBICI, LAURENTIU DINCA, LILIOARA SURDU

National Research \& Development Institute for Textiles and Leather,

Lucretiu Patrascanu no.16, 030508 Bucharest, Romania

\section{Corresponding author:}

